\title{
Secondary production of Jassa slatteryi (Amphipoda, Ischyroceridae) on a Zostera marina seagrass bed in southern Korea
}

\author{
Seung Jin Jeong ${ }^{1}$, Ok Hwan Yu' ${ }^{2}$, Hae-Lip Suh ${ }^{1, *}$ \\ ${ }^{1}$ Department of Oceanography, Chonnam National University, Gwangju 500-757, Korea \\ ${ }^{2}$ Marine Living Resources Research Division, Korea Ocean Research and Development Institute, Ansan 425-600, Korea
}

\begin{abstract}
On the basis of monthly samples, we measured the secondary production of the amphipod Jassa slatteryi Conlan 1990, on a Zostera marina L. seagrass bed in Gwangyang Bay, southern Korea. The standing crop of seagrass showed 2 peaks in spring and fall, with maximum biomass in May. Biomass distribution of $J$. slatteryi was positively correlated with the standing crop of seagrass ( $p<0.05)$, suggesting that there is a biological interaction between these 2 species. J. slatteryi displays 2 main breeding periods during the year; in spring (March to May) and in fall (October to December). The biomass of $J$. slatteryi and the standing crop of seagrass in the spring was much higher than in the fall. The annual secondary production of $J$. slatteryi in the Gwangyang Bay seagrass bed (20.07 $\mathrm{g}$ dry weight $\mathrm{m}^{-2} \mathrm{yr}^{-1}$ ) is the highest reported in amphipods inhabiting seagrass beds. However, the annual production:biomass $(P: B)$ ratio, at 5.21, was lower than recorded previously in both temperate and tropical seagrass beds because the number of generations decreases the $P: B$ ratio. The combination of high abundance and secondary production suggests an important role for $J$. slatteryi in the seagrass-bed ecosystem as a trophic link from primary producers to higher consumers.
\end{abstract}

KEY WORDS: Secondary production · Seagrass bed $\cdot$ Jassa slatteryi

Resale or republication not permitted without written consent of the publisher

\section{INTRODUCTION}

Seagrass beds are among the highest producing habitats of marine ecosystems and, from a trophic structure point of view, occupy an important position in coastal ecosystems (Thayer et al. 1984). Seagrass meadows support a high abundance and diversity of associated fauna, microphytobenthos and microorganisms (Stoner 1980, Cariou-Le Gall \& Blanchard 1995), which are consumed by higher predators (e.g. crabs, fish, and waterfowl) utilizing the seagrass beds as feeding areas (Thayer et al. 1975). A notable feature of seagrass beds is the high density of invertebrate fauna (resident infauna and epifaunal invertebrates) relative to that in adjacent, unvegetated habitats (Orth et al. 1984). The abundance and density of invertebrate fauna in seagrass beds is an important factor determining production in coastal ecosystems.
Small and migratory isopods, amphipods and mysids are characterized by rapid turnover rates (Drake \& Arias 1995), and may predominate in seagrass beds (Jeong et al. 2004). In particular, amphipods are considered to be one of the most important secondary producers in seagrass beds (Fredette \& Diaz 1990). Amphipods utilize primary food sources such as detritus and phytoplankton, and are in turn prey for higherlevel consumers such as fishes and large crustaceans (Nelson 1979, Vetter 1995, Derrick \& Kennedy 1997).

The amphipod crustacean Jassa slatteryi Conlan, 1990 is an epibenthic, abundant species of intertidal vegetated habitats, living at a depth of about 1 to $30 \mathrm{~m}$ below spring tide low water (Barnard 1958, Hong 1983). On the basis of a year-round survey, Jeong et al. (2004) reported that $J$. slatteryi was a dominant species on the Zostera marina L. seagrass bed of southern Korea. A few studies have briefly addressed the distri- 
bution and systematics of J. slatteryi (Hong 1983, Jeong et al. 2004). Many studies have been carried out on the secondary production of amphipods (see Yu \& Suh 2002). However, most of these studies were concentrated on amphipod species inhabiting unvegetated habitats. The secondary production of amphipods in seagrass beds remains largely unknown. Moreover, no attempts to measure secondary production of $J$. slatteryi have been made. The objectives of this study are 2-fold: (1) to measure the annual variation of biomass and (2) to estimate the secondary production of $J$. slatteryi on seagrass beds in southern Korea.

\section{MATERIALS AND METHODS}

Sampling. The sampling station was a sublittoral seagrass bed surrounded by rock in the northwestern part of Namhae-do, Gwangyang Bay (Fig. 1). Tidal levels were measured as the distance $(\mathrm{m})$ above and below mean sea level (MSL) at Gwangyang (NORI 2002). The annual tidal range varied from $415 \mathrm{~cm}$ above to $22 \mathrm{~cm}$ below MSL. The seagrass beds along the shoreline and are 10 to $30 \mathrm{~m}$ wide and 90 to $100 \mathrm{~m}$ long. Water temperature and salinity ranged from 9.2 to $26.4^{\circ} \mathrm{C}$ and from 10.9 to $31.6 \mathrm{psu}$, respectively (Fig. 2). During the rainy season, the lowest salinity in August was clearly linked to the runoff of Seomjin River near the sampling station.

Epibenthic amphipods on Zostera marina seagrass leaves were sampled monthly from January to Decem-

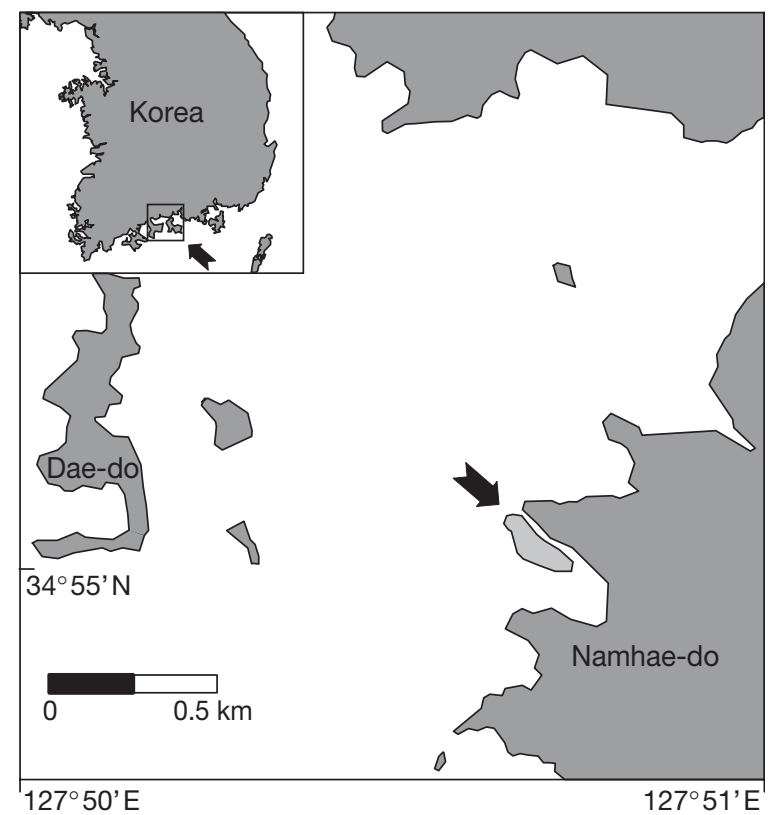

Fig. 1. Location of the sampling site in Gwangyang Bay, southern Korea. The arrows indicate the seagrass bed investigated
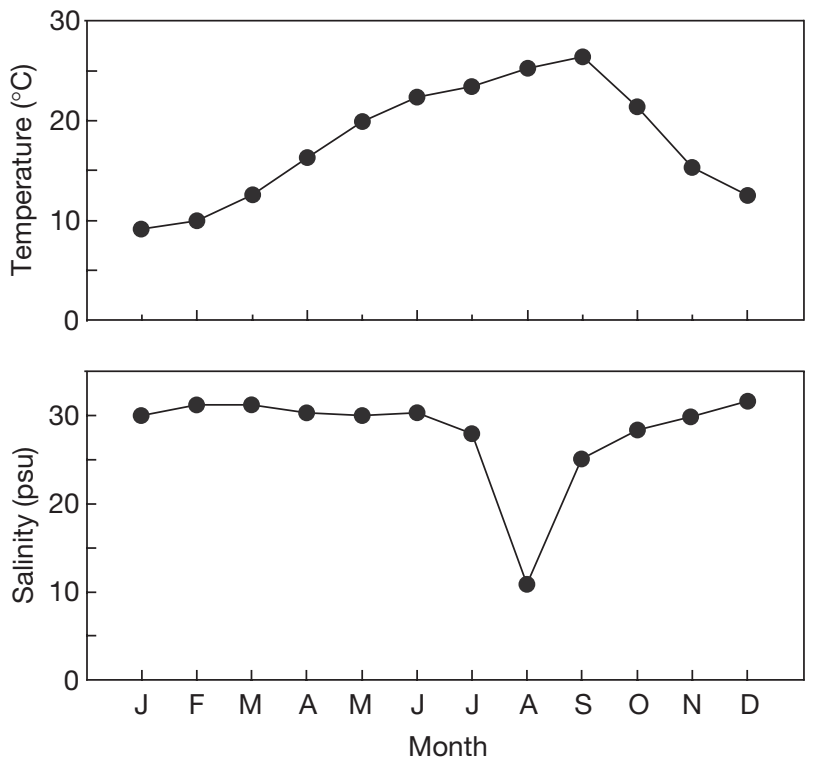

Fig. 2. Monthly variation of temperature and salinity

ber 2002 at the spring tide low water mark. Three replicate samples were collected using a diver-operated hand-held net $(15 \times 15 \mathrm{~cm}$ mouth, $0.15 \mathrm{~mm}$ mesh size). The hand-held net was carefully placed over seagrass and covered form the tip of leaves to the shoot rhizome. Next, the mouth of the net was closed before cutting the rhizomes. To avoid disturbance of sediment, sampling was carried out in the upper $\sim 15 \mathrm{~cm}$ of the water. The seagrass samples were transported to the laboratory, where the animals were separated from seagrass by rinsing with filtered sea water.

The dry weight (DW) of seagrass was measured after drying for $24 \mathrm{~h}$ at $60^{\circ} \mathrm{C}$ and weighed to the nearest $0.01 \mathrm{~g}$ using an electronic microbalance (Mettler Instrument, UMT2). The animals separated were immediately preserved in $5 \%$ borate-buffered formaldehyde with filtered sea water. Individuals of Jassa slatteryi were sorted and counted under a dissecting microscope. The size of individuals was determined by measuring the length of the animal from the tip of the rostrum to the end of the telson under a stereomicroscope fitted with an image analysis system (Image Pro Plus 2.0).

Biomass. Additional samples to measure biomass were collected from March to May 2004. After collection, live individuals of Jassa slatteryi were sorted under a dissecting microscope and placed separately in a vial filled with filtered sea water. They were transported to the laboratory to clear the gut. Next, all live $J$. slatteryi were incubated for $48 \mathrm{~h}$ without food. After incubation, live animals were rinsed with distilled water and their body length (BL) measured in $\mathrm{cm}$. For DW measurement, specimens were dried for $24 \mathrm{~h}$ at $65^{\circ} \mathrm{C}$ and individually weighted to the nearest $0.1 \mu \mathrm{g}$ 
using an electronic microbalance (Mettler Instrument, UMT2). The regression of DW (in mg) was obtained in an equation of the form: $\mathrm{DW}=a \mathrm{BL}^{b}$, where $a$ and $b$ are constants.

Secondary production. Because the cohorts of amphipods inhabiting seagrass beds were difficult to separate, secondary production of Jassa slatteryi was estimated using the size-frequency method. The conceptual basis of this method is the use of the average size-frequency distribution to sum the total losses between size groups based on samples taken monthly throughout the year. Benke's (1979) modification of the basic production equation of Hynes methods (Hynes 1961, Hamilton 1969) is used here:

$$
P=\left[I \sum_{j=1}^{i}\left(\bar{N}_{j}-\bar{N}_{j+1}\right) \times \sqrt{\bar{W}_{j} \bar{W}_{j+1}}\right] \times(365 / C P I)
$$

where $P$ is the annual production, $I$ is the number of times loss factor, $i$ is the number of size classes, $N_{\mathrm{j}}$ is the mean number of individuals in size class $j$ (averaged over the entire year), $W_{j}$ is the mean DW of individuals in size class $j$, and $C P I$ the cohort production interval (in days) from hatching to reaching the largest size class. When a difference in maximum length between females and males occurred, we selected the lower times loss factor to avoid overestimation of production (Waters \& Hokenstrom 1980). The annual production was the summation of the production of each size class multiplied by $365 / C P I$ to account for multiple broods (Benke 1979). The life cycle of $J$. slatteryi is nearly 1 yr (S. J. Jeong unpubl. data), therefore the value of $365 / C P I$ was not modified. The accuracy of the size-frequency method increases with the use of smaller size intervals (Cushman et al. 1978). Because the mean size of newly hatched juveniles of $J$. slatteryi was $0.75 \mathrm{~mm}$ (see Fig. 4), we used $1 \mathrm{~mm}$ size classes to estimate secondary production.

\section{RESULTS}

\section{Biomass}

The relationship between the standing crop of seagrass and biomass of Jassa slatteryi was highly significant (Pearson's correlation test, $\mathrm{n}=185, \mathrm{r}^{2}=0.88, \mathrm{p}<$ 0.05). The standing crop of seagrass showed 2 peaks throughout the year (Fig. 3). The standing crop increased from $60 \mathrm{~g} \mathrm{DW} \mathrm{m}^{-2}$ in February to $838.51 \mathrm{~g}$ DW $\mathrm{m}^{-2}$ in May and then decreased to $240.43 \mathrm{~g} \mathrm{DW}$ $\mathrm{m}^{-2}$ in August. After September, the standing crop increased again and reached a value of $338.60 \mathrm{~g} \mathrm{DW}$ $\mathrm{m}^{-2}$ in November.

The significant relationship between BL and DW of Jassa slatteryi is presented by the regression equation:

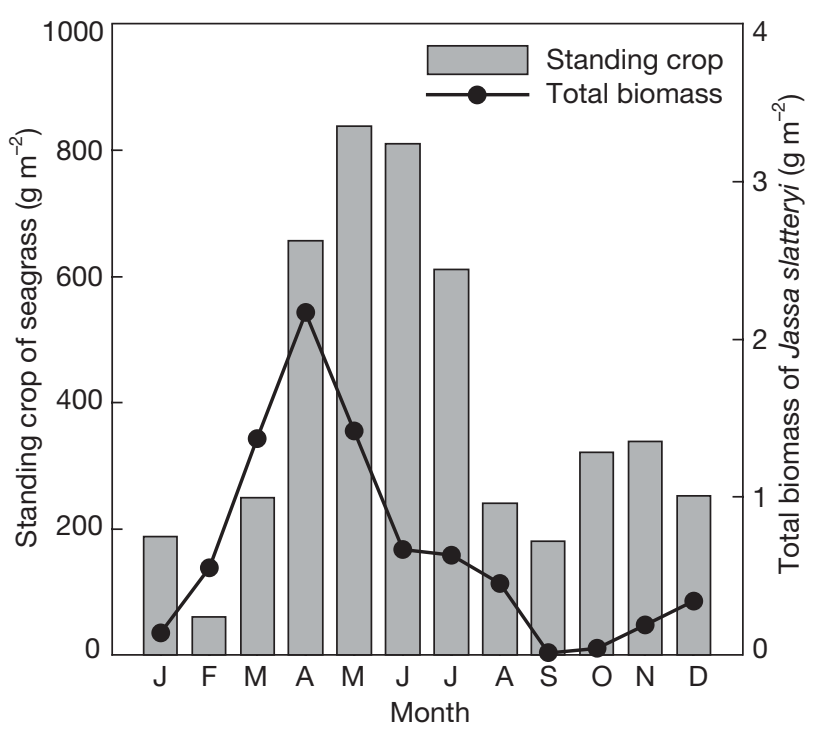

Fig. 3. Jassa slatteryi. Seasonal variation in total biomass (DW) of J. slatteryi and the standing crop (DW) of seagrass

$\mathrm{DW}=0.0048 \mathrm{BL}^{2.44}\left(\mathrm{n}=131, \mathrm{r}^{2}=0.87, \mathrm{p}<0.05\right)$. Biomass distribution of $J$. slatteryi was similar to the variation pattern of the standing crop of seagrass, and showed 2 peaks in April and December (Fig. 3). It rapidly increased from $0.14 \mathrm{~g} \mathrm{DW} \mathrm{m}^{-2}$ in January to $2.27 \mathrm{~g} \mathrm{DW}$ $\mathrm{m}^{-2}$ in April and then decreased to $0.01 \mathrm{~g} \mathrm{DW} \mathrm{m}^{-2}$ in September. The biomass increased again and showed a value of $0.34 \mathrm{~g} \mathrm{DW} \mathrm{m}^{-2}$ in December.

Biomass of Jassa slatteryi is also closely related to the growth periods of seagrass (Fig. 3). The biomass of each size class was lower in the early fall than in the other seasons, but the proportion of small individuals was higher in fall (Fig. 4). The total biomass was very low in late summer and winter (Fig. 3). Biomass of small individuals $(<3 \mathrm{~mm})$ was greater than that of large individuals $(>3 \mathrm{~mm})$ in spring and fall, whilst the biomass of large individuals increased during spring and early winter before the breeding period (Fig. 4). In the spring and fall breeding periods, the BL of $J$. slatteryi ranged from 3.0 to $8.0 \mathrm{~mm}$. Mean DW of $J$. slatteryi was very high during fall and then rapidly decreased in the early winter (Fig. 5). Maximum mean DW was $17.12 \mathrm{mg} \mathrm{m}^{-2}$ in November. Density was negatively related to mean DW (Fig. 5).

\section{Production}

Before the estimation of secondary production, the number of times loss factor was reduced from 10 to 9 because the maximum lengths of males and females were 8.25 and $9.75 \mathrm{~mm}$, respectively. The total produc- 

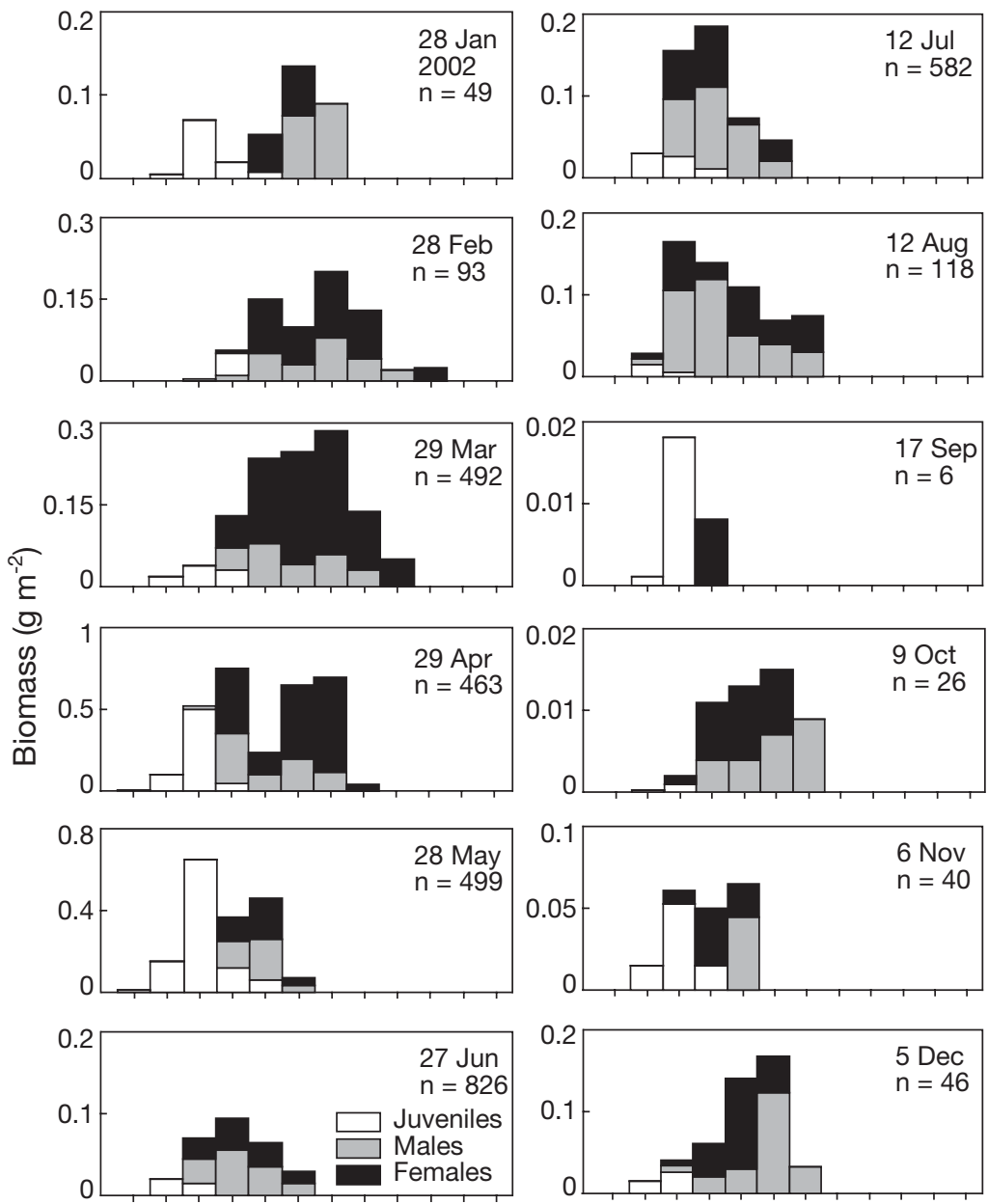

T)

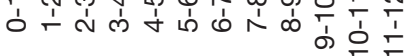

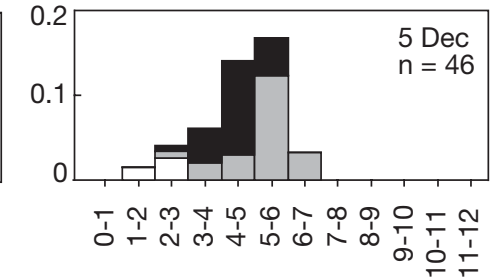

Size class $(\mathrm{mm})$

Fig. 4. Jassa slatteryi. Seasonal variation in biomass (DW) structure

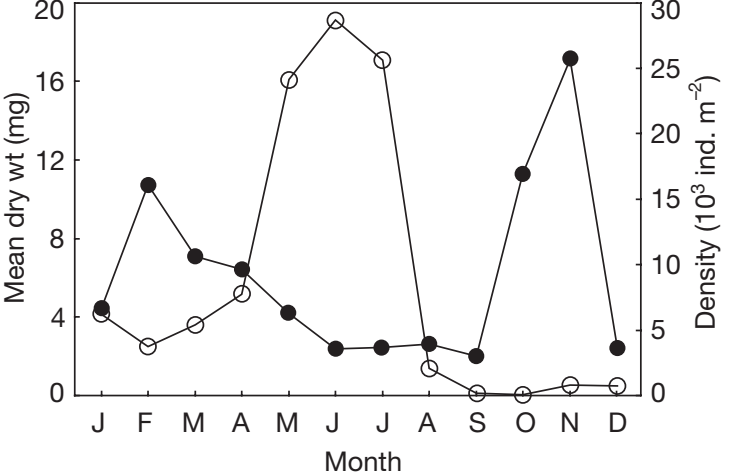

Fig. 5. Jassa slatteryi. Seasonal variation in mean DW (๑) and density (O)

tion of Jassa slatteryi was estimated as $20.07 \mathrm{~g}$ DW $\mathrm{m}^{-2} \mathrm{yr}^{-1}$, and annual biomass as $3.85 \mathrm{~g} \mathrm{DW}$ $\mathrm{m}^{-2} \mathrm{yr}^{-1}$. The annual $P: B$ ratio was estimated as 5.21 (Table 1).

\section{DISCUSSION}

Based on foregut content analysis, Jeong et al. (2004) reported that the main food items of Jassa slatteryi consist of seagrass tissues and benthic diatoms. Thus, J. slatteryi is a herbivorous feeder. The growth pattern of seagrass was closely correlated with the biomass structure of $J$. slatteryi, as was previously observed by Fredette \& Diaz (1986) for Gammarus mucronatus. The growth of seagrass is clearly linked to the secondary production of J. slatteryi.

Marine amphipods exhibit a wide range of secondary production according to species and

Table 1. Jassa slatteryi. Estimation of secondary production of J. slatteryi on the seagrass beds of Gwangyang Bay by the sizefrequency method. Biomass expressed as DWs. No. lost: lost individual number between 2 successive size groups; Wt. at lost: geometric mean of individual weights between 2 successive size groups; wt. lost: lost production in each size group; No. times lost: number of size groups through which $J$. slatteryi grows

\begin{tabular}{|c|c|c|c|c|c|c|c|c|}
\hline $\begin{array}{l}\text { Size group } \\
(\mathrm{mm})\end{array}$ & $\begin{array}{l}\text { Density } \\
\left(\text { No. } \mathrm{m}^{-2}\right)\end{array}$ & $\begin{array}{l}\text { Mean wt } \\
(\mathrm{mg})\end{array}$ & $\begin{array}{l}\text { Standing stock } \\
\qquad\left(\mathrm{g} \mathrm{m}^{-2}\right)\end{array}$ & $\begin{array}{l}\text { No. lost } \\
\left(\mathrm{m}^{-2}\right)\end{array}$ & $\begin{array}{l}\text { Wt. at lost } \\
\text { (mg) }\end{array}$ & $\begin{array}{l}\text { Wt. lost } \\
\left(\mathrm{g} \mathrm{m}^{-2}\right)\end{array}$ & No. times lost & $\begin{array}{l}\text { Production } \\
\quad\left(\mathrm{g} \mathrm{m}^{-2}\right)\end{array}$ \\
\hline $0-1$ & 44.45 & 0.00 & 0.00 & -1009.52 & 0.01 & -0.01 & 9 & -0.06 \\
\hline $1-2$ & 1053.97 & 0.01 & 0.01 & -11292.25 & 0.03 & -0.28 & 9 & -2.55 \\
\hline $2-3$ & 12346.22 & 0.05 & 0.58 & 4065.04 & 0.07 & 0.29 & 9 & 2.60 \\
\hline $3-4$ & 8281.18 & 0.11 & 0.88 & 4065.31 & 0.15 & 0.60 & 9 & 5.37 \\
\hline $4-5$ & 4215.87 & 0.20 & 0.85 & 1053.97 & 0.25 & 0.26 & 9 & 2.37 \\
\hline $5-6$ & 3161.90 & 0.31 & 0.98 & 2159.20 & 0.38 & 0.82 & 9 & 7.37 \\
\hline $6-7$ & 1002.70 & 0.47 & 0.47 & 949.37 & 0.55 & 0.52 & 9 & 4.70 \\
\hline $7-8$ & 53.33 & 0.65 & 0.03 & 26.66 & 0.77 & 0.02 & 9 & 0.18 \\
\hline $8-9$ & 26.67 & 0.91 & 0.02 & 8.89 & 1.02 & 0.01 & 9 & 0.08 \\
\hline \multirow[t]{2}{*}{$9-10$} & 17.78 & 1.15 & 0.02 & 17.78 & 0.00 & 0.00 & 9 & 0.00 \\
\hline & Total biomass & 3.85 & & $P: B$ ratio & 5.21 & Total production & 20.07 & \\
\hline
\end{tabular}




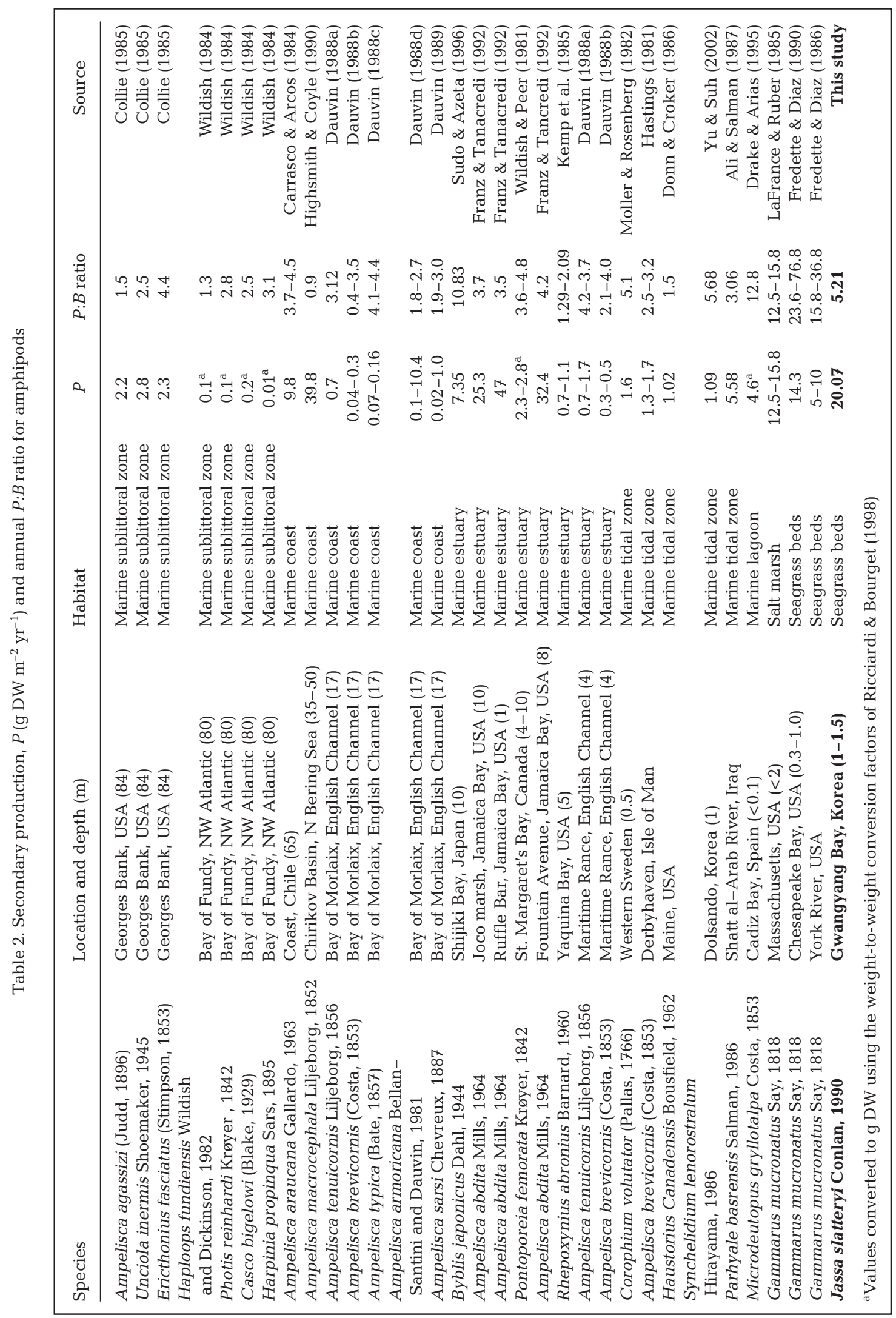


habitat (Table 2). In unvegetated habitats, the highest production value reported was $47 \mathrm{~g} \mathrm{DW} \mathrm{m}^{-2} \mathrm{yr}^{-1}$ for Ampelisca abdita in Jamaica Bay, New York (Franz \& Tanacredi 1992). However, the production of most amphipods inhabiting unvegetated habitats ranges from 0.1 to $15.8 \mathrm{~g} \mathrm{DW} \mathrm{m} \mathrm{gr}^{-1}$; Ampelisca macrocephala is an exception with a production of $39.8 \mathrm{~g} \mathrm{DW}$ $\mathrm{m}^{-2} \mathrm{yr}^{-1}$ in the Bering Sea (Highsmith \& Coyle 1990). In seagrass beds, on the other hand, the highest production value reported was $14.30 \mathrm{~g} \mathrm{DW} \mathrm{m}^{-2} \mathrm{yr}^{-1}$ for Gammarus mucronatus from the lower Chesapeake Bay (Fredette \& Diaz 1990). In this study, the secondary production of Jassa slatteryi was $20.07 \mathrm{~g} \mathrm{DW} \mathrm{m}^{-2} \mathrm{yr}^{-1}$, the highest value for amphipods inhabiting seagrass beds.

The high production measured in this study can be explained in 2 possible ways. One reason could be the difference in mesh size of the sampling nets. To investigate the life cycle of Gammarus mucronatus, Fredette \& Diaz (1986) collected samples using net with a mesh size of $0.25 \mathrm{~mm}$. However, for measuring secondary production, Fredette \& Diaz (1990) used a net with a mesh size of $0.5 \mathrm{~mm}$, without commenting on the change of mesh size. Considering the size of newly hatched juveniles of G. mucronatus, it is possible that juveniles of G. mucronatus were not quantitatively sampled. The size class containing the newly hatched amphipods was the largest of all the size classes of $G$. mucronatus tested (see Fredette \& Diaz 1986, Figs. 8 to 10). We suggest, therefore, that the secondary production of G. mucronatus could have been underestimated. In our study, a hand-held net with a mesh size of $0.15 \mathrm{~mm}$ allowed us to collect all newly hatched juveniles quantitatively, since the smallest newly hatched juveniles of Jassa slatteryi are $0.5 \mathrm{~mm}$.

The second reason for the high production measured in this study could be the large brood size (number of embryos per brood) of Jassa slatteryi. Yu \& Suh (2002) suggested that amphipods with large brood size have a greater chance of survival than those with small brood size. The high survival rate may contribute to success in rebuilding the population of the next generation (Yu et al. 2002) and is directly related to the increase of biomass of amphipods. The mean brood size of Gammarus mucronatus ranges from 15 to 39 eggs (Steele \& Steele 1975, Borowsky 1980), and that of Jassa slatteryi ranged from 31 to 49 eggs per brood. Thus, it is possible that the large brood size of J. slatteryi affects the high secondary production.

It has been empirically demonstrated that the $P: B$ ratios of benthic amphipods are higher in vegetated than unvegetated habitats (Orth et al. 1984). For example, the $P: B$ ratios of Gammarus mucronatus inhabiting seagrass beds ranged from 15.8 to 76.8 , whilst amphipods living in unvegetated habitats were low, ranging from 0.4 to 15.8 (Table 2 ). The annual $P$ : $B$ ratio of Jassa slatteryi was 5.21 (Table 1). Compared with $P: B$ ratios of amphipods inhabiting other seagrass beds, this value is relatively low even if generally higher than in unvegetated habitats (Table 2). Dauvin (1989) reported that the $P: B$ ratio appeared to be closely related to the number of generations. For many generations, a high $P: B$ ratio was evident and was a characteristic of short-lived, multivoltine species (Kemp et al. 1985, Donn \& Croker 1986). The number of generations of $J$. slatteryi was lower than that of other amphipods and we suggest that this causes a decrease of the $P: B$ ratio in $J$. slatteryi.

Seagrass beds provide better habitats for diverse and abundant invertebrate communities than many other habitats (Orth et al. 1984). In seagrass beds, benthic amphipods are an important food for fishes and crustaceans. The high abundance and secondary production of Jassa slatteryi in the seagrass beds depends not only on the high egg production of J. slatteryi but also on the growth of seagrass. It is clear that the dominant herbivorous feeder $J$. slatteryi may play an important role in the energy flow between primary production and higher consumers in the seagrass beds of southern Korea.

Acknowledgements. We thank H. G. Jeong, S. G. Seon and J. I. Park for their assistance in the field and data processing. Thanks are also due to 3 anonymous reviewers for their constructive comments and helpful suggestions on the manuscript. This work was financially supported by a Korean Research Foundation Grant (KRF-2003-015-C00689).

\section{LITERATURE CITED}

Ali MH, Salman SD (1987) Growth and production of the amphipod Parhyale basrensis (Talitridae) in the Shatt alArab region. Mar Ecol Prog Ser 40:231-238

Barnard JL (1958) Amphipod crustaceans as fouling organisms in Los Angeles-Long Beach Harbors, with reference to the influence of seawater turbidity. Calif Fish Game 44: 161-186

Benke AC (1979) A modification of the Hynes method for estimating secondary production with particular significance for multivoltine populations. Limnol Oceanogr 24:168-171

Borowsky B (1980) Reproductive patterns of three intertidal salt-marsh gammaridean amphipods. Mar Biol 55: $327-334$

Cariou-Le Gall V, Blanchard G (1995) Monthly HPLC measurements of pigment concentration from an intertidal muddy sediment of Marennes-Olóron Bay, France. Mar Ecol Prog Ser 121:171-179

Carrasco FD, Arcos DF (1984) Life history and production of a cold-temperate population of the sublittoral amphipod Ampelisca araucana. Mar Ecol Prog Ser 14:245-252

Collie JS (1985) Life history and production of three amphipod species on Georges Bank. Mar Ecol Prog Ser 22: 229-238

Cushman RM, Shugart HH, Hildegrand SG, Elwood JW 
(1978) The effect of growth curve and sampling regime on instantaneous-growth, removal-summation, and Hynes/ Hamilton estimates of aquatic insect production: a computer simulation. Limnol Oceanogr 23:184-189

Dauvin JC (1988a) Biologie, dynamique, et production de populations de crustacés amphipodes de la Manche occidentale. 1. Ampelisca tenuicornis Liljeborg. J Exp Mar Biol Ecol 118:56-84

Dauvin JC (1988b) Biologie, dynamique, et production de populations de crustacés amphipodes de la Manche occidentale. 2. Ampelisca brevicornis (Costa). J Exp Mar Biol Ecol 119:213-233

Dauvin JC (1988c) Biologie, dynamique, et production de populations de crustacés amphipodes de la Manche occidentale. 3. Ampelisca typica (Bate). J Exp Mar Biol Ecol 121:1-22

Dauvin JC (1988d) Life cycle, dynamics and productivity of Crustacea-Amphipoda from the western English Channel. 4. Ampelisca armoricana Bellan-Santini et Dauvin. J Exp Mar Biol Ecol 123:235-252

Dauvin JC (1989) Life cycle, dynamics and productivity of Crustacea-Amphipoda from the western English Channel. 5. Ampelisca sarsi Chevreux. J Exp Mar Biol Ecol 128:31-56

Derrick PA, Kennedy VS (1997) Prey selection by the hogchoker, Trinectes maculatus (Pisces: Soleidae), along summer salinity gradients in Chesapeake Bay, USA. Mar Biol 129:699-711

Donn TE Jr, Croker RA (1986) Seasonal patterns of production in the sandy-beach amphipod Haustorius canadensis. Estuar Coast Shelf Sci 22:675-687

Drake P, Arias AM (1995) Distribution and production of Microdeutopus gryllotalpa (Amphipoda: Aoridae) in a shallow coastal lagoon in the Bay of Cadiz, Spain. J Crustac Biol 15:454-465

Franz DR, Tanacredi JT (1992) Secondary production of the amphipod Ampelisca abdita Mills and its importance in the diet of juvenile winter flounder (Pleuronectes americanus) in Jamaica Bay, New York. Estuaries 15:193-203

Fredette TJ, Diaz RJ (1986) Secondary production of Gammarus mucronatus Say (Amphipoda: Gammaridae) in warm temperate estuarine habitats, York River, Virginia. J Crustac Biol 6:729-741

Fredette TJ, Diaz RJ (1990) Secondary production within a seagrass bed (Zostera marina and Ruppia marina) in lower Chesapeake Bay. Estuaries 13:431-440

Hamilton AL (1969) On estimating annual production. Limnol Oceanogr 14:771-782

Hastings MH (1981) The life cycle and productivity of an intertidal population of the amphipod Ampelisca brevicornis. Estuar Coast Shelf Sci 12:665-677

Highsmith RC, Coyle KO (1990) High productivity of northern Bering Sea benthic amphipods. Nature 344:862-864

Hong JS (1983) Three tube-building amphipods from experimental plates in Deukryang Bay in the southern coast of Korea. Korean J Syst Zool 26:135-153

Hynes HB (1961) The invertebrate fauna of a Welsh mountain stream. Arch Hydrobiol 57:344-388

Jeong SJ, Yu OH, Suh HL (2004) Seasonal variation and feed-

Editorial responsibility: Otto Kinne (Editor-in-Chief), Oldendorf/Luhe, Germany ing habits of amphipods inhabiting Zostera marina beds in Gwangyang Bay, Korea. J Korean Fish Soc 37:122-128

Kemp PF, Cole FA, Swartz RC (1985) Life history and productivity of the phoxocephalid amphipod Rhepoxynius abronius (Barnard). J Crustac Biol 5:449-464

LaFrance K, Ruber E (1985) The life cycle and productivity of the amphipod Gammarus mucronatus on a northern Massachusetts salt marsh. Limnol Oceanogr 30:1067-1077

Moller P, Rosenberg R (1982) Production and abundance of the amphipod Corophium volutator on the west coast of Sweden. Neth J Sea Res 16:127-140

Nelson WG (1979) Experimental studies of selective predation on amphipods: consequences for amphipod distribution and abundance. J Exp Mar Biol Ecol 38:225-245

NORI (National Oceanographic Research Institute, Korea) (2002) Tide Tables, Vol 510. NORI, Inchon

Orth RJ, Heck KL Jr, Van Montfrans J (1984) Faunal communities in seagrass beds: a review of the influence of plants structure and prey characteristic on predator-prey relationship. Estuaries 7:339-350

Ricciardi A, Bourget E (1998) Weight-to-weight conversion factors for marine benthic macroinvertebrates. Mar Ecol Prog Ser 163:245-251

Steele DH, Steele VJ (1975) The biology of Gammarus (Crustacea, Amphipoda) in the northwestern Atlantic. XI. Comparison and discussion. Can J Zool 53:1116-1126

Stoner AW (1980) The role of biomass in the organization of benthic macrofaunal assemblage. Bull Mar Sci 30: $537-551$

Sudo H, Azeta M (1996) Life history and production of the amphipod Byblis japonicus Dahl (Gammaridea: Ampeliscidae) in a warm temperate zone habitat, Shijiki Bay, Japan. J Exp Mar Biol Ecol 198:203-222

Thayer GW, Wolfe DA, Wiliams RB (1975) The impact of man on seagrass systems. Am Sci 63:288-296

Thayer GW, Bjorndal KA, Ogden SL, Williams RB, Zieman JC (1984) Role of larger herbivores in seagrass communities. Estuaries 7:351-376

Vetter EW (1995) Detritus-based patches of high secondary production in the nearshore benthos. Mar Ecol Prog Ser 120:251-262

Waters TF, Hokenstrom JC (1980) Annual production and drift of the stream amphipod Gammarus pseudolimnaeus in Valley Creek, Minnesota. Limnol Oceanogr 25:700-710

Wildish DJ (1984) Secondary production of four sublittoral, soft-sediment amphipod populations in the Bay of Fundy. Can J Zool 62:1027-1033

Wildish DJ, Peer D (1981) Methods for estimating secondary production in marine Amphipoda. Can J Fish Aquat Sci 38:1019-1026

Yu OH, Soh HY, Suh HL (2002) Life history and reproduction of Synchelidium lenorostralum (Amphipoda, Oedicerotidae) in a temperate sand shore, southern Korea. J Crustac Biol 22:126-134

Yu OH, Suh HL (2002) Secondary production of Synchelidium lenorostralum (Amphipoda, Oedicerotidae) on a temperate sandy shore, southern Korea. J Crustac Biol 22: $467-473$

Submitted: March 8, 2005; Accepted: August 6, 2005

Proofs received from author(s): February 15, 2006 